\title{
Verbatim Theatre :
}

History and Techniques

\author{
A paper submitted by: \\ Anas Mohamed El Sayyed El Desouqi \\ M.A. of English Drama \\ Faculty of Arts \\ Tanta University
}

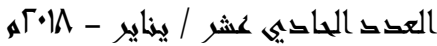




\section{Abstract}

Theater has always been the mirror reflecting the spirit of the age with which it deals. In other words, if you want to know the history of a certain nation, you have better to resort to its theatre. There, you can become acquainted with this nation's cultural, political, social, moral and religious heritage. This fact is embodied by verbatim theatre, a new dramatic genre born out of documentary theatre. Verbatim theatre is a theatre necessitated by the need of the late $20^{\text {th }}$ and early 21 rst centuries for a dramatic form capable of dealing with the pains, sufferings and disappointments experienced by the people living during the two centuries. From this point, comes the aim behind this research, which is to trace the history and techniques of this new genre of theatre. 


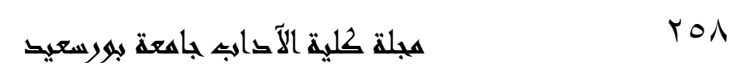

\section{Verbatim Theatre: \\ History and Techniques}

Historically, Theatre has a crucial role, which is to expose the important events of its age. Thus, when studying a history of a certain era, theatre is the best tool to resort to in such a study. Theatre provides a full picture of this era's cultural, political, social, moral and religious heritage, from this function, comes the importance of theatre. This fact is embodied by verbatim theatre, a new dramatic genre born out of documentary theatre. Verbatim theatre is a theatre necessitated by the need of the late $20^{\text {th }}$ and early $21^{\text {th }}$ centuries for a dramatic form capable of dealing with the pains, sufferings and disappointments experienced by the people living during the two centuries. With journalism fettered by the most powerful country in the world, dramatists began to search for a new form with which to deal with the exigencies of the situation imposed by the States. The new form happened to be the verbatim, a form more frankly able than journalism to tackle such thorny issues. However, to trace the history and techniques of the new genre, there should be a historical study of the origin, from which the verbatim theatre came. This origin comes to be the Documentary Theatre.

Documentary Theatre has its deep roots in history that need to be investigated. In all eras, theatre has a role to show the customs and traditions of nations. Such a role, led to the creation of a genre utilized to deal with recent historical, cultural, and political events to be documented on stage. Later on, with the spread of this genre of theatre all over the world, it

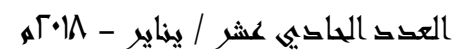


started to be developed according to the age it deals with in order to satisfy its needs. Accordingly, the genre has been given several unique names. Nowadays, with the development of events all over the world, particularly on the political side, analyzing and discussing these political matters become something urgent. As a result, Media started to shed the light on the political issues that arose in $20^{\text {th }}$ and early $21^{\text {st }}$ Century. However, with the appearance of what is called nowadays the 'Power States', Media became captivated by these States, which affected and limited its abilities of covering the political events. With the development of devices to document events, such as newspaper reports, radio, and the invention of television, and later on, face to face interviews, theatre started to utilize these devices to enable it to cope with the modern political events. This genre has been given the name "Verbatim". Verbatim theatre has the devices Media use in covering events and the power and independency that media lacks because of the manipulation of Power States over it when dealing with the thorny political events. Soans argued for the importance of verbatim theatre, as a sort of arts, she states: "The arts are more than mere entertainment. In my view they should be the vessel which houses the conscience of a nation; they should ask the difficult questions others would rather leave unasked" (Boles $158)$.

In the last two centuries, theatre playwrights and producers in Europe start to resort to documentary performances to confront the new sociopolitical crises. This kind of theatre, which depends on documented 
materials, has existed as a genre along with the existence of theatre itself. Professor of Theater Arts at the University of Pittsburgh, Attilio Favorini, states that the first dramatic documentary play was produced in 429 BC by the ancient Greek playwright Phrynicus, who produced The Capture of Miletus, a play about the Persian War. The development of the documentary theatre resulted in the appearance of the newly developed theatre: the verbatim theatre. Derek Paget was the first to use the term 'verbatim' during his researches on documentary drama, which involves recorded material from real-life transcripts of real characters and events. Seeking for a more accurate form, Paget offers his question:

"why not bypass the factuality of the documentary to create invented models that show the critical problem more efficiently, more intelligently and artistically? Why not complete the act of surrogation by releasing the ethical obligation to actuality source material?" (Hammond and Dan Steward 74).

Derek Paget's question can be considered as a starting point for the development of theatre in general and of the verbatim theatre in particular, which focuses on dramatizing the critical political events all over the world.

In a more detailed presentation of the history of Documentary Theatre, which verbatim theatre evolved out of, its history has been divided to be discussed in certain countries where this kind has been developed and acted: Germany, Britain and America. However, there are other countries 
where documentary theatre is found such as Poland, South Africa, Russia, etc.

Documentary Theatre, also called 'Theatre of Fact', is a German dramatic movement that arose during the early 1960s, associated primarily with Rolf Hochhuth, Peter Weiss, and Heinar Kipphardt. Their political plays examined recent historical events, often through official documents and court records. In its modern form, documentary theatre was pioneered by two famous German authors and directors: Bertolt Brecht and Erwin Piscator in the 1920s. On the one hand, Brecht was a German poet, playwright, and a theatre practitioner of the 20th century, and he made contributions to dramaturgy and theatrical production. On the other hand, Piscator was an influential 20th-century German theatre director who was considered one of modernism's most important theatre practitioners. In Brecht's and Piscator's plays, they focus on issues of social conflict, class tensions and power structures. Essentially derived from Brecht and Piscator's Epic Theatre, Piscator developed his own 'Living Newspaper' in the 1930s. Erwin Piscator's play Trotz alledem!, which was acted in Berlin in 1925, is acknowledged as the first stage documentary. To be more precise, there are three major periods of German documentary theatre: the emerging genre in the 1920s with the theatre of Erwin Piscator; the documentary drama in the 1960s; and, beginning in the late 1990s, the new forms of alternative and independent theatre that are highly experiential and question the conception and performance of historical discourses. 
Out from the 'Theatre of Fact' in Germany, came the English verbatim theatre to occupy a central place on the British stage, and is seen as one of the most insightful forms of political theatre. Such insightful forms appear in the works of the English playwrights. Such English playwrights include David Hare, whose verbatim (or at least part-verbatim) plays The Permanent Way (2003), Stuff Happens (2004) and The Power of Yes (2009) were all performed at the National Theatre; and in particular the work of director Nicholas Kent and the Guardian journalist Richard Norton Taylor at the Tricycle Theatre in London. Kent and Norton-Taylor's work has included a series of tribunal plays, including Nuremberg (1996), and perhaps their most successful production: The Colour of Justice: The Stephen Lawrence Enquiry (1999), Bloody Sunday (2005), and Called to Account (2007). All these were edited scenes from court cases. Gradually, verbatim theatre moves on to be the leading genre to chronicle and depict the recent thorny political events for people on the stage faithfully and accurately.

While documentary theatre has its roots in Germany moving up to Britain, it is important to take into consideration the rise of this form in America. In $20^{\text {th }}$-century America, there have been three significant moments of innovation in the form and content of documentary performance:

The first movement of the rise of the verbatim theatre in America was known by the works produced under the sponsorship of the Federal Theater Project (1935-1939). Their "Living Newspapers" used a form borrowed from the 'agitprop', which was a sort of a propaganda, and worker's theatre 
popular in early twentieth-century Europe and the Soviet Union to address significant political and economic issues of the day. While their content was based on fact-based materials, the forms of these early documentary plays were modernist in their essence, expressionism and plainness staging. This tension between factual content and expressionist form remains a symbol of the documentary theatre genre.

The second movement of the rise of the verbatim theatre in America appeared during the social disorder of the late 1960s, where public unrest regarding Civil Rights, the Vietnam War and economic injustices. These critical events required a new generation of playwrights and theatre companies, such as The Living Theatre and the Open Theatre, to employ the documentary form as a way to question dominant media narratives as well as overcome the boundaries of expected theatrical form and performance space. At this time, documentary artists built upon the notion of "fact-based" material with the belief that everyday life and individual, personal experiences provided suitable domains and material for documentary performances. Autobiographical solo performances, which are a one-person show featuring a comedian or actor who stands on stage and entertains an audience and multi-media installations are just a few of the innovations from this era.

The third movement of American documentary theatre, or rather, the beginning of the modern American theatre, was built upon the solo performances of Anna Deavere Smith in the late 1980s. This period was 
characterized by cooperative development of the theatre performance among directors, designers, playwrights, actors and their documentary subjects: living and dead. The dominance of written archival documents has decreased and interview-based materials have become central moving up to the modern documentary theatre.

The modern Documentary theatre that was developed in all these countries to cope with the needs of the new era, paved the way to the creation of the verbatim theatre. Verbatim theatre acquired the power enough to deal with the critical issues of the age, the political issues in particular. The emergence and development of the verbatim theatre to discuss such critical events in history, and to deal with the thorny issues nowadays, put it in a challenging situation against Mass Media. Although Media has the capability of showing and discussing such social and political issues, or showing the 'critical problem' as expressed by Paget, there is a factor that makes theatre simpler, more interesting and more focused:

In the theatre you have the interaction between actors and audience, but also, as a journalist, it's much more rewarding to have something like 30,000 words to create two hours of theatre in which people can actually see the beginning and the end, and different aspects of an issue or controversy. That's almost impossible in journalism, unless you have a long essay or something (Brown 2). In this respect, we notice the competition that arose between verbatim theatre and Mass Media with its various forms in the efficiency of covering 
the critical events in the 21rst Century, and in particular, on the political side.

The controversy that surfaced between theatre and Media on the covering of the thorny political events is a matter of great importance. The political potential of verbatim is a type of new public sphere in which issues and information that may otherwise be forced underground by big Media interests, for example, can be resurfaced. In an interview with Mark Brown concerning the directors of the verbatim play Called to Account, Nicolas Kent and Richard Norton Taylor, Brown states in his article "Blair in the dock":

Both director and writer believe that the theatre is the best possible forum for debates about important political disputes like the occupation of Iraq. "Theatre is a great medium for presenting contemporary issues that aren't, perhaps cannot be, adequately or properly articulated in newspapers, television or radio,' says NortonTaylor. (2).

Brown continues to argue in his article adding:

For Kent, as a dramatist, there is a world of difference between presenting the arguments around a major political issue on television and doing the same thing at the theatre. 'In the theatre you have quite a lot of time to wrestle with an issue, whereas television programmes are fast and punchy. Television programmes can't be a slow burn in the way that theatre productions can: they can't accumulate ideas and issues; they have to go immediately for the 
jugular. The other problem with television is, you don't have a communal feeling while watching it. You watch it, on the whole, in a room with one or two other people, or by yourself. The relationship, when you watch television, is sterile, because you can't influence it in any way. In the theatre people laugh at things that are ridiculous in the evidence, or they become bored or angry, giving the whole thing a much more visceral feeling.'

If the "liveness" of theatre creates a sense of tension and public debate which television can't achieve, perhaps that suggests that the theatre is closer to the courtroom than people might think. Kent sees a direct parallel: 'Quite a lot of barristers would tell you that in their early career, while they were training, they were actually actors. (2).

Theatre is considered as the strongest kind of Media, therefore, nowadays, lights are shedding on this form, which seeks to restore its remarkable position that has been lost. Currently, theatre has the courage enough to criticize the thorny political issues that face the World and has the ability to get the audience more interactive with the events than it is the case while watching news on Television, for example. Andrew, a critic, states, talking about Richard Tylor's Called to Account:

There could be few bolder political fantasies today than imagining Tony Blair being investigated by the International Criminal Court to see whether he could be indicted for aggression against Iraq. It could not happen. Yet such a dream, cherished by hundreds of thousands, 
now springs to startling stage-life thanks to those remarkable makers of contemporary political theatre, director Nicolas Kent and Richard Norton-Taylor, security editor of The Guardian. (Andrew 1).

David Hare found the verbatim technique an attractive means of exploring the political nature of what lead up to the war in Iraq in his verbatim play Stuff Happens:

Many of the playwrights crafting verbatim theatre pieces believed that the press had failed in their duty to question the political decisions being made post-September 11, as the information was being entirely controlled by the governments. Hare stressed that verbatim theatre "does what journalism fails to do (Boles 143).

Nowadays, verbatim theatre is not merely a building or a stage on which actors perform their roles; rather, it is the people, who create answer to their needs and beliefs. It gives voice for the voiceless, by acting, or rather, documenting history on stage.

Techniques in Verbatim Theatre:

Verbatim theatre has its own distinctive techniques and terms to be explored. A verbatim play is sometimes based on something such as a disaster, a particular incident, political issues or a dramatic event. One of the best techniques involved in this genre is the use of Dialogue. The dialogue of verbatim theatre uses the real words from interviews to construct the play: "Verbatim Theatre is a form of theatre which places interviews with people at the heart of the process and product, since such interviews provide a 
foundation from which a script is developed that is then performed by actors". (Heddon 115). However, in order not to mingle the verbatim play with the created play, there is a difference to be noted between what is 'verbatim', and what is 'created'. for the 'verbatim' play, on the one hand, usually the audience expect the theme of the play; that is to be 'political', and that they will watch real events, unlike the 'created' play, on the other hand, in which there is fiction and created scenes by the playwright:

One of the main differences between 'created' and 'verbatim' plays lies in the expectations of the audience. The audience for a verbatim play will expect the play to be political; they will be willing to accept an unconventional format; they will probably expect the material to be contentious and to challenge their opinions. At least they will expect to be surprised by some of the revelations on offer. Simply by choosing to put a subject under the theatrical microscope, the playwright is saying 'There's more to this than meets the eye' or 'History relates this to be the case; I think it needs to be reexamined', or even 'I found this so interesting I would like to share it with you .. .it might change your opinions'. Above all, the audience for a verbatim play will enter the theatre with the understanding that they're not going to be lied to. They may be unsettled by the unusual way the play is constructed, but they will be compensated for the lack of convention by the assumption that what they are looking at and listening to is revelatory and truthful (Hammond and Steward 11). 
Verbatim theatre aims to make the audience participate in the events unfolding before their eyes. So, it aims to keep the audience well aware of the fact that they are watching a play and not real life. It aims to make the audience think about what they are seeing.

To discover deeply the techniques involved in verbatim theatre, an analysis of three verbatim plays has been done. Those plays are Stuff Happens by David Hare, Called to Account by Richard Norton Taylor, Fallujah by Jonathan Holmes. Moreover, the relationship between verbatim theatre and ethics is a critical theme that needs to be debated. In addition, how to be close with the audience in a verbatim play is another important theme to be discussed.

The aim of the verbatim theatre is not something easy to achieve; it needs certain strategies to be applied in the play. This depends on the talent of the playwright. In the Elizabethan Drama, particularly the Shakespearian plays, the playwright does his best to engage the audience in the play with the characters. For example, Shakespeare uses techniques to make the audience share the events of the play. Such techniques are like soliloquy and aside. Recently, the playwrights try to invent new ways and techniques to make the role of the audience more active. They make the communication between the characters and the audience more direct. Will Hammond and Dan Steward in their book entitled Verbatim Verbatim: Techniques in Contemporary Documentary Theatre narrate an experience that clarifies this development in creating interaction with the audience: 
Suppose I went to interview Mo Mowlam. She talks to me; I write down her words, and then edit them into a speech, or in some cases into dialogue between her and her husband. We then cast June Watson in the role. She sits on a chair on stage and talks to an audience, just as the original Mo Mowlam talked to me. By this process, the audience have become me, or whomever I happened to be with when I conducted the interview, and the Mo Mowlam on stage talks to the audience on a purely personal and confidential level. Every member of that audience begins to feel, 'this woman is sharing the intimate details of her life with me ... her hopes, her regrets, her dilemmas, her innermost thoughts ... She's speaking off the record with a frankness that she could never show in her public life ... She even reveals her penchant for broken biscuits .' Transferring a deeply personal conversation onto to the stage in this way confers a responsibility on the audience - a responsibility which I think they enjoy - and this partially accounts for the increased intensity of their listening.

Further encouraging the audience's involvement must be the care they develop for the characters. How many times after a show have I heard people say, 'I didn't enjoy it very much; I didn't care for any of the characters'? The chief reason for this failure is that the characters seem somehow artificial and therefore difficult to relate to. Artificiality is a charge that cannot be raised against the verbatim 
playwright unless he or she is a complete charlatan. Actually, when the bricks and mortar of a play are real conversations, people use such idiosyncratic and bizarre language that it is immediately recognisable as lacking in artifice (13).

Verbatim theatre playwrights seek to create real atmosphere in their plays as well as to create intimacy between the audience and the events of the play. In Stuff Happens, David Hare evokes the real political atmosphere of the Bush administration presenting it to the audience as if it were an open book. He uses certain techniques that help create such an atmosphere. A case in point is the use of the dialogue interweaved with the monologue. David Hare intermingles between scenes that depend on dialogue to show us the veil Bush's administration members wear when they talk to people and follow these scenes with one depending on monologue as in Act I, scenes 4-5, where there is a meeting of Bush's administration to discuss the issues of the middle east, and following that scene by a monologue of an angry journalist criticizing their policies. Such scenes helps uncover their hidden intentions and shows how contradict this administration are between themselves. The angry journalist summarizes their promises for their claim to achieve democracy asking: "what is the word for those who claim to love democracy...?" (1.5.16). This is a feature of the play made by David Hare, which is to create a series of monologues by various anonymous characters such as an American professor who compellingly argues the case for war, a Palestinian student who wonders how it came to pass that the victims 
became the problem in the Israeli/Palestinian conflict and an Iraqi who draws a parallel between Iraqis and the US expressing his sadness about his country for not depending on itself saying: "Don't expect America or anybody will do it for you"(2.24.120). These 'viewpoints' are intended to give voice to every man and woman affected by the events dramatized and to open the minds and imagination of the audience during the progress of the play. Moreover, we have the role of the unnamed actors to define us the members of the Bush's administration. Nameless actors in Stuff Happens also guide some of the action, and there are a few separate monologues (a 'Palestinian Academic', an 'Iraqi Exile') adding texture and background to the play.

Verbatim theatre is skillfully constructed to create theatre that is not merely a reconstruction of an event but also an entertaining piece of theatre. This can be done using many techniques. Such techniques include recordings and voice-overs. In Jonathan Holmes' Fallujah, voiceover is one of the technical aspects used in the play as a kind of storytelling. Voiceover, also known as off-camera or off-stage commentary, is often a necessary and justified technique that can complement and heighten the on-screen/stage drama. It is a production technique where a voice, that is not part of the narrative, is used in a radio, television production, filmmaking, theatre, or other presentations. The voice-over may be spoken by someone that appears elsewhere in the production or by a specialist voice actor. It is pre-recorded and placed over the top of a film or video, and commonly 
used in documentaries or news reports to explain information. Likewise, Voice-over technique is used to give voices and personalities to animated characters. Voice-overs are often used to create the effect of storytelling by a character or omniscient narrator. For example, in Fallujah, Jo, a character in the play, in the 'Kidnapping scene' narrates her experience of being kidnapped in a form of voice-over, showing what the questions that come to your mind are when you are kidnapped. In that scene, the stage fades to black where the voice-over starts: "What do you do when you're kidnapped in Iraq? What do you do? You look for ways out. You wonder whether they are going to kill you, make demands for your release, if they'll hurt you. You ..." (2.14.180). Sometimes, voice-over can be used to aid continuity in edited versions of films, in order for the audience to gain a better understanding of what has gone on between scenes. The voice-over has many applications in non-fiction as well; Television news is often presented as a series of video clips of events with voice-over being used by the reporters who describe the significance of the scenes being presented. Live sports broadcasts are usually shown as extensive voice-overs by expert announcers over video of the sporting event. Furthermore, Recorded Voice Delivery is another important technique of verbatim theatre to be noted where the actors listen to recorded interviews during their performance, so as to correctly imitate exact words and phrases, accents and speech mannerisms of the actual person represented by the character. Alecky Blythe, who is a British playwright and screenwriter, has her "recorded 
delivery" technique, which she used in her shows The Girlfriend Experience and Do We Look Like Refugees? In these shows, we observe actors wearing headsets, mimicking word for word and intonation for intonation of the recordings she made of her subjects.

In Germany, in Erwin Piscator's play Trotz alledem!, Piscator utilized new technologies, which included creating montages using projected documentary footage. Trotz alledem! also featured recorded speeches, news-extracts, photographs and film sequences from the First World War. Regardless of Piscator's use of new film projection technologies, it is noticed that this form, the verbatim theatre, is closely linked to a simple technological development: the invention of the portable cassette recorder. This enabled the voices of individuals to be recorded and documented in their own environment. With the development of the recording sets, Mobile interviews could take place, which extended the dramatic possibilities of verbatim theatre.

Juxtaposition is one of the devices used in verbatim plays. In literature, juxtaposition is putting two contradicting ideas, characters, objects, etc. side-by-side or in similar narratives for effect. Usually, juxtaposition is used to add development to the storyline or characters. It is applied variously to opposing emotions, abstract concepts, character traits and values, or images. Juxtaposition is a very effective technique to enhance the quality of a play. Not only does it convey to the audience that what they are watching is not real life, but also it can create entertainment, dramatic 
tension and excitement. Jonathan Holmes' mastery in writing the scenes of Fallujah appears in his manipulation of Juxtaposition. To create Irony, Holmes gets fact-based evidences narrated by witnesses and puts it in reply to statements by US Spokesmen or government leaders in certain scenes that contradict what are said by the witnesses in an ironical manner. By following such a way of making the scenes, the playwright creates some sort of mockery of the US policy in Iraq and shows its policy like an open book to the audience to read. Consequently, Holmes follows the technique of juxtaposition in the play, which helps him to be neutral as well as to reveal the US cunning policies. Thus, he makes it clear for the audience that what the US government states is opposite to what they do in fact. For instance, In Act II, scene VII, On-screen scene watched by Sasha, Rana narrates an evidence she has witnessed. In that scene, she narrates that she was looking for a woman left with a blind old man in the house, when she entered into the house, she started calling but received no reply, she went out of the house and noticed something in the garden and it was a body with the color, green. Rana wonders: "it was a body with the color green, and I have never seen this in all my life" $(2.7 .170)$. This footage made by Rana is a reply to the Pentagon Spokesman at the same scene who states, "Napalm has not been used in Iraq. We use Mark 77 incendiary. The US took napalm out of service in the 1970s. We completed the destruction of our last batch of napalm on 4 April 2001, and no longer maintain any stocks of napalm." (2.7.170). The critical method Holmes follows in the play 
mocks the US administration and puts it in an ironic situation to prove its cunning policy, which was showed as being clear, straightforward by Media. In his article, 'The legacy of Fallujah', Holmes states:

In writing my play Fallujah, which weaves together eye-witness accounts from Rana and many others present during these attacks, what astonished me was the symmetry between the testimony of American soldiers and that of their victims: 'Yeah, we napalmed those bridges," said Colonel Randolph Alles, of Marine Air Group 11, in an interview with James Crawley of the San Diego Union-Tribune. 'The generals love napalm.' The guys on the ground no longer bother dissembling, so confident are their masters that protest, should it happen, will be muted and ineffectual (1).

Moreover, in Fallujah, most scenes alternate, with one scene being present tense and the next scene being past tense. This contrasts or juxtaposing scenes and events give the audience insight into things that may otherwise go unnoticed. The play compares past events with current events to help the audience understand the effects that past events have on Iraq, and on Fallujah, in particular. We notice the results of the assault on Fallujah at the end of the play, showing the complete demolition of the city in all fields.

Direct and indirect addresses are also one of the techniques used in Fallujah. This technique helps the audience to participate in the action they are watching and not to be merely passive spectators. Briefings and lectures 
occur in different spaces on stage so that the audience perspective is constantly shifting. In 'The Sniper' scene, Act II, scene XII, the sniper addresses his speech directly to the audience, explaining to them how Fallujah is an easy place where you can snipe and no one will know your place.

Form another perspective, direct and indirect addresses to the audience, and giving briefings and lectures occur in different spaces on stage, create some sort of alienation in the verbatim theatre. Alienation is a term used in verbatim theatre. It is the idea that alienating a particular action will shed light on a certain aspect of the play. It is used so as the audience do not forget that the play is not real, though it is a verbatim play, by making sure the audience do not let themselves get too caught up in the character and emotions. In the plays of Bertolt Brecht, Brecht forcibly seeks to remind the audience that they were watching a performance. Brecht never wanted the audience to believe that they were emotionally in sync with the characters. By breaking conventions, such as having the actor's speak directly to the audience, Brecht created 'the alienation effect'. This allowed the audience to view the play from a critical, rather than emotional, standpoint.

The flexibility of the verbatim theatre is another feature that distinguishes it from all other kinds of theatre. Verbatim theatre allows recorded media and radio to be shown and broadcast on stage along with the acting process of the characters during the play. Michael Billington 
argues in his article to the guardian " $\mathrm{V}$ is for verbatim theatre" that: "Today verbatim, as both process and product, is not merely everywhere. It is has proved itself infinitely flexible" (1). This flexible nature of the verbatim play is what helps playwrights to perform their verbatim play as it should be; for they need the stage to embody several kinds of Mass Media. For example, In Fallujah, the stage can be a TV show in a scene, and in the following scene, we may see a press-briefing scene, and a battlefield in another scene. Moreover, there is audio scenes in Act II, scene IX and X. This variety of shows and staging different places in each scene are what distinguishes verbatim theatre from all other works of art. It also makes the plays more interesting. Furthermore, the multiplicity of scenes and events makes us, as audience, feel the rapidity of the play progress in a harmonic way. For example, in Act I, scene I, there is an interview of A/ Jazeera, here, the stage is supposed to be the TV studio while the audience is considered to be a studio audience. In Act I, scene II, there is a press briefing followed by scene III where we notice some actors are watching these reports in the previous scenes and commenting on them by direct address to the audience in some sort of storytelling. Making Interviews in the play is a way to allow the Narrative mode to be applied and it is used to convey certain plots to the audience. Moreover, we see onscreen scenes being watched by some actors who comment on what is broadcast to the audience in another way of storytelling. Therefore, from another perspective, using Media devices in the verbatim theatre is another way for providing 
evidence; for it can be considered a sort of intelligences that approve what is said during the play.

Another merit added to the verbatim theatre because of its flexible nature is the compatibility of scenes with the events. Such compatibility is found in Fallujah. The progress of Fallujah develops depending on the scene played. For instance, when the attack on Fallujah is about to start, in Act II, scene 19, scenes run speedily and energetically to cope with the situation, which is the progress of the attacks on Fallujah. The compatibility of the scenes with the events is what makes the play coherent and shows a sort of harmony in the progress of the play. Such a technique in the order of scenes makes the play much more close to reality or real life.

Another technique Holmes uses in Fallujah to make his play more realistic is that sophisticated soundscape in the background during the play, which has a significant role not only providing naturalistic assistance, but also an active player. Much of what happens in the play is done orally and it is the function of the sound to give the audience a clear sense of what is to be in Fallujah at this time. Jonathan Holmes asserts that "Aural scenography is limitless in the theatre, whereas the visual is restricted" (148). Here comes the importance of the background sound in the play that helps also the audience to identify actions leading to a sense of suspense. Background sound may be considered the replacement of the role of the visual effects on the audience. One of the tremendous scenes where the audience feel in action is scene $\mathrm{XI}$, it is the assault on Fallujah. Here, in 
this scene, the stage is changed to be just like a battlefield; the stage goes black, and heavy metal music is played very, very loudly. There is also the sound of artillery and small arms fire. Same effects are in scene XXI, the Attack on Fallujah, where the audience hear explosions punctuated with noise bombs, which is unbearable, in addition to gunshots, mortars and machine gun fire. Such sounds help at achieving the exact atmosphere of a real battlefield that allows the audience to be in action, consequently, to be close to reality.

Audio scenes are a way to create auditory images in Fallujah, and are also one of the most important elements that cause the play to be more realistic. In Fallujah, as we see in Act II, scene X, there is an audio scene describing a wounded Iraqi man crawling across the floor. Exhausted, he slumps to the floor. An American soldier walks and sees him. After a moment, the soldier pulls out a pistol, and shoots him twice in the head and he repeats the same aggressive action towards another dead body. This audio scene dramatizes the aggressiveness of the American administration in Iraq, not only have they violated rights of the living humans, but also the dead. In act III, scene 22, a doctor, interviewed by Sasha, narrates the horrible events happening to Eyad's family during the attacks on Fallujah. He describes what happened to Eyad's family at the end to the audience: "The five survivors, including the six-month old child, lay in the street, surrounded by the blood of their families, for seven hours. Then four of them crawled to the nearest home to find shelter" $(3.22 .194)$. Such visual 
images are created because of the Narrative mode used in Fallujah, which makes the play look like a novel in certain scenes, and urges the audience to develop their imagination of the events narrated.

Moreover, the manipulation of the lights on stage reinforces the creation of a real atmosphere and helps gather more than one place at the same time on stage. In Fallujah, Act III, scene XV, there is a speech by Condoleezza Rice. Here, the playwright can just put the character of Condoleezza on a stand and let her address her speech to the audience, but the skillfulness of Holmes appears in his masterful use of lights; He put three kinds of people on stage: Condoleezza on screen, and there are two groups in the right and left of the stage: one group is watching the speech on a small television and the other hearing the speech on a radio. The lights are focused on Rice then it dims on her, but with no effect on her screen persona. At the same time, it is focused on one group and then transferred to the other group, and back again to Rice's speech on TV. In this way, lights are being exchanged from one group to another indicating three places at the same time in one scene. By following such a way in dealing with lights, Holmes creates more reality in his play.

Jonathan Holmes' use of soliloquies in Fallujah is also one of the techniques used to reveal facts within a verbatim play. Soliloquy is a device in drama where the character or the actor is alone on stage speaking frankly about his innermost thoughts to himself allowing the audience to know his real views. This is a way of closing the distance between actors and the 
audience and creating interaction between them. A soliloquy can be found in Act IV, scene 31, where Rana asks herself a question and answers it herself.

In creating a mixture of multiple voices, verbatim performances usually allow for multiple points of view arranged side-by-side. This technique is defined by Michael Bakhtin as 'Polyphony'. Alison Jeffers states that in a verbatim play, there is a wide range of voices and opinions to be listened to, she states:

Watching a verbatim play can feel like being washed over by a great tide of voices, feelings and opinions... verbatim theatre is a lesson in suppression; more material is recorded that can ever be used. It is manipulated, crafted and edited to create an effect. The spectator's freedom to meander within this, to create their own patterns, logic and narratives may, ultimately, prove a false one whereby the constructed nature of the playwright's vision is concealed from the audience by the very wash of the voices and the apparent lack of any narrative line (Jeffers 6).

In literature, polyphony is a feature of narrative, which includes a diversity of points of view and voices. Mikhail Bakhtin is the first to introduce the concept. The term is based on the musical concept 'polyphony'. Polyphony means 'multi-voicedness'. It arises in fiction when the special position of the author allows great freedom of interaction to the characters; the characters in a polyphonic work of art are allowed maximum freedom so that 
they could argue with each other and even with their author. That is, in polyphonic plays, different centers of consciousness are allowed to interact in the play. Bakhtin's theory is sometimes called 'dialogics'. Dialogics or dialogism, according to Bakhtin, means the process by which meaning is evolved out of interactions among the author, the work and the reader/listener. These elements are in turn influenced by the context in which they are placed. In Polyphonic plays:

The author does not place his own narrative voice between the character and the reader, but rather, allows characters to shock and subvert. It is thus as if the books were written by multiple characters, not a single author's standpoint. The reader does not see a single reality presented by the author, but rather, how reality appears to each character. The text appears as an interaction of distinct perspectives or ideologies, borne by the different characters. The characters are able to speak for themselves, even against the author - it is as if the other speaks directly through the text. The role of the author is fundamentally changed, because the author can no longer monopolise the 'power to mean' (Robinson 4).

Bakhtin attacked the conventional idea of the work of art as a finished or limited product. According to him, a work of art will live only if it is engaged in a dialogue. Dialogue is possible only in works that are not closed, in works that are still open, in polyphonic works in which their authors do not retain the final word about their characters. The dialogue in 
such a work is facilitated by the highly independent characters who are capable of interacting with each other as well as with their author. Bakhtin considers the double-voiced discourse the 'chief hero' among various novelistic discourses. Dialogic relations are relations like agreementdisagreement and affirmation-negation that might arise between any two utterances. As already mentioned, the peculiarity of a polyphonic play is that the characters are absolutely free from authorial control. The voice of the author is never dominant and the characters 'answer back' with great freedom. The technique of polyphony is used by the playwrights of the three verbatim plays mentioned earlier. They followed such a technique to avoid being one-sided.

Hare's Stuff Happens was accused of being an anti-war play. To avoid being anti-war playwright, Hare uses the polyphony. He uses the polyphonic technique to subvert any one-sided dimensional reading of the play. Hare says he spoke confidentially to dozens of people involved in the events he portrays. He gives complete freedom to his characters in the play to give their views. In the dialogue between the members of the US administration, President Bush, Rice, Colin Powell, Rumsfeld, we get to know their views on the invasion of Iraq. For example, on the one hand, Rumsfeld justifies the shameful looting and pillaging of Baghdad in just one phrase, "Stuff Happens!" he argues: "Think what's happened in our cities when we've had riots, and problems, and looting. Stuff Happens!" (1.2.3-4). On the other hand, we have the Iraqi Exile at the end of the play who 
expresses his anger because of the US policies in his country, he states: "I left my country twenty-seven years ago. I longed for the fall of the dictator. In exile, I worked for it. Then Donald Rumsfeld said, 'Stuff Happens.' It seemed to me the most racist remark I had ever heard", he goes on to indicate that the US administration violated human rights and hides the horrible results after the attacks ended, "And now the American dead are counted, their numbers recorded their coffins draped in flags. How many Iraqis have died? How many civilians? No figure is given. Our dead are uncounted" (2.24.120). Thus, while Rumsfeld views invasion as a blessing for the Iraqis, the Iraqi at the end of the play regards it as a disaster.

In Richard Norton Taylor's Called to Account, the technique of polyphony is used. The play depends on interviews between the Prosecutions of the court and the Defense who ask the witnesses to give their testimonies in a detailed patient way to the court. For instance, in the first scene, act I, we encounter a Kurdish exile, Dr. Sherwan Al-Mufti, who describes Iraqi torture and who argues: "In my opinion, or the majority of the Iraqi people, the regime of Saddam Hussein, it was our weapon of mass destruction itself" (1.1.17). He metaphorically considers Saddam to be their WMD. He offers his own opinion freely to the court. However, another witness, Richard Perle, argues that the intelligences asserts Iraq's possession of WMD, "The intelligence community believed with great conviction that Saddam Hussein possessed weapons of mass destruction" (2.5.78). Therefore, the Kurds regard Saddam as a menace to them; 
Richard Perle deems him a threat to the West because of the WMD possessed by him. Another witness is Michael Quinlan. He argues that even if Saddam committed violations of human rights against his people, it is not legal to use regime change as justification to invade Iraq:

Certainly he ranked very high among disagreeable rulers, but I took and take the view that in the current state of the international system, both legal and more broadly political, there isn't a right to remove such people by force. Perhaps there ought to be, but there isn't (2.6.87).

The prosecution, Sands, asserts Quinlan's view when he tells Al Mufti that: "this is what the Attorney General says in July 2002: 'the desire for regime change was not a legal base for military action" (1.1.15). On the contrary, when Sands asks Mr. Smith to interpret a paragraph quoted from a conversation at the British war cabinet on 23 July 2002, which indicates that: "When the British Prime Minister discussed Iraq with President Bush at Crawford in April, he said the UK would support military action to bring about regime change provided that certain conditions were met", Smith interprets that paragraph saying: "It [the Paragraph] is saying that Mr Blair has told President Bush that he is going to back military action to achieve regime change. He's going to back an invasion of Iraq, It can't be read any other way" (1.3.26). Other witnesses in the play narrate their views liberally. Thus, multiplicity of voices is achieved in the play to avoid being a onesided play. In short, here we get three different points of view concerning 
the removal of Saddam Hussein. The first party supports the removal of Saddam because of his threat to the Iraqi people; the second is of the opinion that Saddam must be toppled due to the threat to the West of the WMD he possesses. The third party is against regime change.

The overwhelming theme of Fallujah, which is the US administration's violation of human rights in Fallujah, makes the play look like a onedimensional play. To avoid this, and to be neutral, Jonathan Holmes followed Bakhtin's technique: Polyphony. In Fallujah, we see the play written in a polyphonic way. It is composed up of scenes with a wide variety of voices and views. In fact, we notice two parts of characters in the play: There is one party talking and defending their policy followed in Iraq, represented in the speeches of Condoleezza Rice whether being interviewed or in a direct speech through TV in Press conferences. This party, the defending one, also includes US General, Luce, the French journalist who narrates his hijacking experience, commanders from the US army who participated in the attacks, and dialogues between the US soldiers giving their views about the attack. In Act III, scene 23, there is a dialogue among the US soldiers after retreating from a bombardment. Soldier 1 , soldier 2 and soldier 3 are exchanging their views, narrating their experience in Fallujah. The conversation is held half between themselves and half with the audience as a sort of interaction. The other party, on the contrary, is the one who witnessed the violations and cruelty of the US soldiers including Rana, Ahrar, Jo, Fallujah civilians and doctors interviewed by Sahsa. In Act 
$I V$, scene $X X V I$, for example, Jo and Rana exchange narrating the horrible adventures they have experienced with each other during the siege of Fallujah, showing how heartless the US soldiers are toward the civilians of Fallujah. All these voices and this variety of views in the play is what makes Holmes a neutral playwright in writing Fallujah. In this regard, the character of Sasha has an important role in the play; she is a reporter who holds interviews with both sides and who gives the opportunity for each party to express his views. The character of Sasha helps achieving balance in the play and consequently applying polyphony in a good way. Thus, the audience is offered various points of views and not just from one side only.

Another question arose which is what does verbatim theatre offer oral historians or what makes it different from them? One thing that verbatim offers us is the possibility of oral historians and performers working together, a melding of crafts into one. Interviewing and transcribing are central to the oral historian's craft. The editing of transcripts into a script is much related to a playwright and actors. Therefore, verbatim theatre transforms oral history and written interviews into performances on stage, thus allowing a great deal of interaction between the audience and the transcripts. For Jonathan Holmes, presenting verbatim work in a site-specific context is integral to its impact:

One of the principal reasons for doing work that's wholly verbatim", he explains, "is that it gets you much closer to the experiences of real people... With a found text, putting it in a found 
space takes an audience even further towards communicating more directly with the experiences that you're trying to communicate to them (Caird 3).

Regardless of what Oral historians do in documenting history, and of what Media presents from its different branches on politics, the environment, or economics that are put in the spotlight, there's nothing quite like hearing someone's true story in his own words acted on stage as it is the case in verbatim theatre.

From another perspective, telling one's story of a certain suffering event in one's life to verbatim theatre playwrights, in itself, in addition to delivering his voice to others, gives the teller some sort of relief. One of the benefits of the verbatim theatre is psychological effect on the person who experiences the story. Some interviewees are keen to talk about their experiences of suffering and oppression. Talking, especially about what is perceived to be shocking events, which have usually caused doubt and confusion, may help to heal the sufferer:

Recovering repressed memories and articulating them as stories--the so-called talking cure has been recognized as a powerful therapeutic technique... yet in all human societies, recounting one' $s$ experiences in the presence of others is a way of reimagining one's situation and regaining mastery over it. Stories enable people to renegotiate retrospectively their relation with others, recovering a sense of self and of voice that was momentarily taken 
from them. This is dramatically brought home by the effects of victimimpact statements at sentencing hearings when, by publicly voicing their pain and anger, grieving families reclaim some sense of general recognition of the humanity that the murder or rape of their loved one look away from them (Jackson 23).

However, if this recovered voice and sense of self are then betrayed by theatre practitioners, whose aims are focused on the making of the verbatim theatre piece and in the interview on which it is based, in addition to lack of transparency and honesty, then another act of oppression may be reenacted on the original victims instead of causing relief to them innerly.

Another issue to be discussed in the verbatim theatre is the transformation of what is Oral into a transcript performed on stage. Verbatim theatre attempts to be the second source or commentary on a particular historical event or person. The conversion of recorded history taken from face -to- face interviews into theatrical performance is at the heart of the discussion of techniques of verbatim theatre, as a dramatic genre. When it comes to the relationship between what is Oral and transforming it to performance, certain points should be taken into consideration: methodology and ethics of the interview and what is gained and lost in transcription. While the authority of the verbatim transcript is in its 'authentic' rendering of what was said during the interview, it has also its limits; verbatim transcription fails, to a great extent, to capture body language and the rhythm of the spoken word by the witness. A great deal of emphasis is 
placed on the authenticity of the stories being performed on stage, yet, it is not the aim of the verbatim theatre to give authenticity top priority in writing a verbatim play. In the introduction of Jonathan Holmes' verbatim play Fallujah, Holmes asserts that the aim of this play is not to create a full picture of the city of Fallujah, simply because this is not the role of the verbatim theatre here. Holmes argues: "My own starting point in writing this play has therefore been that it is impossible to present a fully authentic picture of the situation in Fallujah" (142). Holmes argues that the purpose behind the play is not to make Fallujah look like a besieged city and it is a misunderstanding of the play to think so. The point is that Holmes seeks not to give authenticity the authority that controls the play through focusing on photographic mimicry and how the witness looks like and how he smiles. However, Derek Paget gives the name "Observing the Process" the focus on such small details of the Photography and of those of the witness. In "Observing the process", Paget notices how the actors explore the character behind the stories, making various choices about small gestures and expressions, accent, and articles of clothing as markers of identity.

While some playwrights insist that every word spoken onstage should originate in the interview material, others use a combination of verbatim and self-authored material as in David Hare's Stuff Happens. Hare has his own purpose of creating a combination of verbatim and self-authored material in Stuff Happens. He may use this combination to add creativity to his verbatim play. Richard Norton Taylor states in his article to the Guardian, "Verbatim 
theatre lets the truth speak for itself", that making a 'pure verbatim' play may decrease the creative part in the play, he argues: "Others, notably Hare in The Permanent Way and Stuff Happens, have mixed verbatim material from speeches or reports with original writing... Maybe pure verbatim theatre is less creative, but it lets people speak for themselves" (2). Moreover, in his play Stuff Happens, for example, David Hare combines fact and fiction without affecting the 'raw material' of the play in order to show the aesthetic part of his work of art:

David Hare argues, the fact that the people in his plays actually exist and the words in his plays were actually spoken by them in no way alters his role as a dramatist. The real world provides him with the raw material, which, as Max Stafford-Clark puts it, he leaves 'raw', but he must still craft a drama from it. The stone of Michelangelo's David is 'real' stone he didn't make it himself- but the sculpture is no less the creation of his skill, imagination and hard work. (Hammond 5).

Nevertheless, verbatim theatre's heavy dependence on the authenticity of the material is what gives it a certain power to reach audiences, one of the great merits and techniques of that sort of theater. However, the techniques involved in the verbatim theatre are various.

Verbatim theatre is a democratic one; it gives every character the right to be heard. In consequence, the marginalized, the disempowered are given the chance to be heard. In other words, those who cannot express 
their own views, their own painful experiences are given the chance to express their points of view freely and without restrictions. "Isn't it the noblest function of democracy to give a voice to the voiceless?" (2), said David Hare in his article to The Guardian, "Guide to reality". Of course, the verbatim technique alone is not enough to make a piece of theatre resound with an audience. As with all performance works, success depends on the talents of the entire creative team along with the vision of the playwright. Conclusion

Verbatim theatre is that genre which revived the theatrical works and popularity that were disappeared after the works of Shakespeare and the $16^{\text {th }}$ Century drama. 'Verbatim' has been the term utilized by Derek Paget. It has proved itself a strong tool in the $21^{\text {st }}$ Century in confronting the critical and sensitive political issues. With its technical flexibility, verbatim theatre asserts its ability to cover and present thorny political issues, issues which are, if not impossible, difficult to be dealt satisfactorily with by Mass Media. While Media uses videos and interviews to show events to the audience, verbatim theatre has a wide variety of ways and devices to show the events. Such ways and devices are made by the performance of actors, news onscreen, radio. Moreover, such devices include using narration and creating a real atmosphere of the event aimed to be broadcast to the audience through making use of the lights and background sounds as in Jonathan Holmes' Fallujah. In other words, verbatim theatre is a factbased simulation of events on stage. This type of theatre derived from the 
documentary theatre managed, to a great extent, to discuss and stimulate daring matters and to reveal or at least to investigate truth. Verbatim theatre achieves a sort of satisfaction to the audience and the public in general by putting certain prominent political characters on stage.

Such verbatim plays provide channels for other voices to be heard. In the plays written in the verbatim style, great emphasis is laid on the witnesses' voice, rather than the playwright's. Therefore, in writing his play in that style, the playwright is neutral; he, in order to avoid being deemed partial, uses the technique invented by Michael Backtin: 'Polyphony', which involves a multiplicity of points of view and voices. In polyphonic plays, the characters are given complete freedom of action. Hence, they do not have to reflect the authors' points of views. This point asserts that verbatim theatre, with all its merits and techniques, is a place where multiplicity of independent voices are heard. Accordingly, verbatim theatre proves that it can handle the central questions of the age faithfully and trustfully. Therefore, anyone who has seen a piece of verbatim theatre done well will be able to attest to the power of the genre.

Works Cited

Andrew, Robinson. "In Theory Bakhtin: Dialogism, Polyphony and Heteroglossia". Ceasefiremagazine.co.uk. 29 July 2011. Web. 26 January 2014. <https://ceasefiremagazine.co.uk/in-theory-bakhtin-1/>. 
Andrew. "Called to Account: A review of the indictment of Tony Blair". Craigmurray.org.uk. 27 April 2007. Web. 2 October 2013. <https://www.craigmurray.org.uk/archives/2007/04/called_to_accou/>.

Boles C., William. The Argumentative Theatre of Joe Penhall. North Carolina: McFarland \& Company. 22 March 2011.

Brown, Mark. "Blair in the dock". Interview. Socialistreview.org.uk. May 2007. Web. 8 July 2014. <http://socialistreview.org.uk/314/blair-dock>.

Caired, Joe. "Verbatim theatre". ideastap.com. 22 March 2011. Web. <http://www.ideastap.com/ldeasMag/knowledge/verbatim-theatre-bradford>.

Hammond, Will and Steward, Dan. Verbatim Verbatim: Techniques in Contemporary Documentary Theatre. London: Oberon Books Ltd. 15 July 2008.

Hare, David. Stuff Happens. London: Faber \& Faber, 2004.

Heddon, Deirdre, Susan C. Haedicke, et al. Political Performances: Theory and Practice. New York: Rodopi. 2009.

Holmes, Jonathan. Fallujah. London: Constable \& Robinson, 2007.

Holmes, Jonathan. "The legacy of Fallujah". Guardian. 4 April 2007. Web. 1 November 2013.

Jackson, Michael. Minima Ethnographica: Intersubjectivity and the Anthropological Project. Chicago: University of Chicago Press, 1997.

Jeffers, Alison. Refugee Perspectives: the practice and ethics of verbatim theatre and refugee stories. London: Royal Holloway University of London. 2006.

Taylor, Richard, N. Called to Account. London: Oberon Books, 2007. 